\title{
Maturation of the GABAergic Transmission in Normal and Pathologic Motoneurons
}

\author{
Anne-Emilie Allain, ${ }^{1}$ Hervé Le Corronc, ${ }^{2}$ Alain Delpy, ${ }^{1}$ William Cazenave, ${ }^{1}$ \\ Pierre Meyrand, ${ }^{3}$ Pascal Legendre, ${ }^{2}$ and Pascal Branchereau ${ }^{1}$ \\ ${ }^{1}$ Institut de Neurosciences Cognitives et Intégratives d'Aquitaine (INCIA), Université de Bordeaux et CNRS-UMR 5287, \\ avenue des Facultés, 4ème étage Est, 33405 Talence, France \\ ${ }^{2}$ INSERM U 952, CNRS UMR 7224, Université Pierre et Marie Curie, Bâtiment B, étage 2, boite postale 37, 7 quai Saint Bernard, \\ 75005 Paris, France \\ ${ }^{3}$ Institut des Maladies Neurodégénératives (IMN), Université de Bordeaux et CNRS-UMR 5293, avenue des Facultés, \\ 4ème étage Est, 33405 Talence, France
}

Correspondence should be addressed to Pascal Legendre, pascal.legendre@snv.jussieu.fr and Pascal Branchereau, pascal.branchereau@u-bordeaux1.fr

Received 10 February 2011; Accepted 17 April 2011

Academic Editor: Evelyne Sernagor

Copyright (C) 2011 Anne-Emilie Allain et al. This is an open access article distributed under the Creative Commons Attribution License, which permits unrestricted use, distribution, and reproduction in any medium, provided the original work is properly cited.

$\gamma$-aminobutyric acid (GABA) acting on $\mathrm{Cl}^{-}$-permeable ionotropic type $\mathrm{A}\left(\mathrm{GABA}_{\mathrm{A}}\right)$ receptors $\left(\mathrm{GABA}_{\mathrm{A}} \mathrm{R}\right)$ is the major inhibitory neurotransmitter in the adult central nervous system of vertebrates. In immature brain structures, GABA exerts depolarizing effects mostly contributing to the expression of spontaneous activities that are instructive for the construction of neural networks but GABA also acts as a potent trophic factor. In the present paper, we concentrate on brainstem and spinal motoneurons that are largely targeted by GABAergic interneurons, and we bring together data on the switch from excitatory to inhibitory effects of GABA, on the maturation of the GABAergic system and $G_{A B A} R$ subunits. We finally discuss the role of GABA and its $G A B A_{A} R$ in immature hypoglossal motoneurons of the spastic (SPA) mouse, a model of human hyperekplexic syndrome.

\section{Introduction}

$\gamma$-aminobutyric acid (GABA) is, with glycine, the major inhibitory neurotransmitter in the adult central nervous system (CNS) of vertebrates. GABA acts on $\mathrm{Cl}^{-}$-permeable ion-otropic bicuculline-sensitive type $\mathrm{A}\left(\mathrm{GABA}_{\mathrm{A}}\right)$ receptors $\left(\mathrm{GABA}_{\mathrm{A}} \mathrm{R}\right)$ and metabotropic baclofen-sensitive $G A B A_{B} \mathrm{R}$, these latter being coupled through G-proteins to $\mathrm{K}^{+}$and $\mathrm{Ca}^{2+}$ channels in neuronal membranes. More recently, it has been shown that GABA also activates $\mathrm{Cl}^{-}$-permeable bicuculline- and baclofen-insensitive $\mathrm{GABA}_{\mathrm{C}} \mathrm{R}$, this receptor subtype being largely expressed in the retina and at lower level in other CNS area [1]. If all GABA receptors are present on the cell membrane, the common view is that $G_{A B A} R$ are presynaptically located, whereas $G_{B B A} R$ and $G A B A_{C} R$ are postsynaptically. However, all GABA receptors seem to be located pre- and/or post-synaptically [2-5].
GABA is synthesized from the amino acid glutamate by the enzyme glutamic acid decarboxylase (GAD), this latter being present as two isoforms with different molecular weights of $65-\mathrm{kDa}$ and $67-\mathrm{kDa}$ [6]. The two GAD isoforms are product of two different genes. GAD65 gene (GAD2) is located on chromosome 10 (10p11.23) in human and on chromosome $2(29.0 \mathrm{cM})$ in mouse, while GAD67 gene (GAD1) is located on chromosome $2(2 \mathrm{q} 31)$ in human and in chromosome $2(243.0 \mathrm{cM})$ in mouse $[7,8]$. In addition, during mouse and rat embryonic development, two alternatively splices forms are also synthesized from the GAD67 gene: the truncated 25-kDA leader (GAD25) and the enzymatically active protein GAD44 (for review, see [9]). GAD25 is a protein without GAD enzymatic activity. GAD25 and GAD44 are expressed during the development of the CNS, they are more abundant in proliferating progenitors [9-11], and they are downregulated during neuronal differentiation 
concomitant with an upregulation of GAD67 expression [12-14]. The 67-kDa GAD form is diffusely distributed in the cytoplasm of the cells, while the $65-\mathrm{kDa}$ GAD form is mainly found attached to synaptic vesicles [15].

During CNS development, GABA exhibits a large panel of activity ranging from the control of cell proliferation to the formation of synapses (for review, see [16-19]). In immature brain structures, most studies described GABA as operating through $\mathrm{GABA}_{\mathrm{A}} \mathrm{R}$ subclass $[18,20]$, and it was first proposed that the other GABAR subclasses were not functional at early stage of life [21]. However, this hypothesis was invalidated by the observation of a pre- and post-synaptic $\mathrm{GABA}_{\mathrm{B}} \mathrm{R}$ expression in the embryonic rat neocortex [22] and the modulation of cortical neuronal migration by $\mathrm{GABA}_{B} \mathrm{R}$ activation [23-25]. $\mathrm{GABA}_{\mathrm{B}} \mathrm{R}$ activation triggers BDNF release and promotes the maturation of GABAergic synapses [26]. Finally, it has been shown that GABA can control the locomotor network in the rat neonatal spinal cord by acting on presynaptic $G_{A B A_{B}} R$ as well as on postsynaptic $\mathrm{GABA}_{\mathrm{A}} \mathrm{R}$ [27]. In the brainstem, it has been recently shown that the interaural time difference detection circuit is differentially controlled by $\mathrm{GABA}_{\mathrm{B}} \mathrm{R}$ during the second postnatal week [28]. An endogenous modulation of respiratory rhythm by $\mathrm{GABA}_{\mathrm{B}} \mathrm{R}$ that increases after birth has also been reported [29]. Finally, functional $G_{A B A_{C}} R$ were detected in the spinal motoneurons (MNs) around birth, but a little is known about the function of these receptors in the immature spinal cord [1].

$\mathrm{GABA}_{\mathrm{A}} \mathrm{R}$-related effects on immature neuronal cells are opposed to those observed on mature neurons in the sense that GABA exerts depolarizing effects during development, while it induces hyperpolarizing effects in most mature CNS regions [30]. Such depolarizing GABA-mediated effects, coupled with conventional excitatory effect of glutamate and other classical neurotransmitters such as acetylcholine, lead to $\mathrm{Ca}^{2+}$ influx and generate spontaneous electrical activities that are the features of almost all immature structures of the CNS [31, 32]. Numerous studies have demonstrated the permissive role of depolarizing GABA in the maturation of neurite outgrowth [33], in promoting both excitatory and inhibitory synaptogenesis [34] and in controlling its switch from depolarizing to hyperpolarizing $[35,36]$.

Brainstem and spinal motoneurons that are largely targeted by GABAergic interneurons require an appropriate maturation of their GABA receptors and GABA innervations. In the present paper, we will describe the ontogeny of the GABAergic system in spinal MNs in parallel to the establishment of an inhibitory transmission, and then we will present data about the maturation of GABA receptors in hypoglossal motoneurons (HMs, motoneurons innervating the tongue) of the spastic (SPA) mouse, a model of human hyperekplexic syndrome in which the impaired glycinergic neurotransmission [37] may be compensated, in certain strain lines, by an increased aggregation of $\mathrm{GABA}_{\mathrm{A}} \mathrm{R}[38,39]$. The hyperekplexic syndrome, as well as the amyotrophic lateral sclerosis (ALS) pathology, highlights the plasticity of the GABAergic system that may temporally compensate genetic alteration of other inhibitory systems $[40,41]$.

\section{Maturation of Chloride-Mediated Inhibition in MNs}

GABA, when binding to $\mathrm{GABA}_{\mathrm{A}} \mathrm{R}$, exerts effects that are mainly dependent upon the chloride equilibrium potential $\left(E_{\mathrm{Cl}}\right)$. In mature neurons, the intracellular $\mathrm{Cl}^{-}$concentration $\left[\mathrm{Cl}^{-}\right]_{\mathrm{i}}$ is lower than extracellular $\mathrm{Cl}^{-}$concentration $\left[\mathrm{Cl}^{-}\right]_{\mathrm{o}}$ and the activation of the chloride permeable channels by GABA induces a chloride influx. However, in immature neurons that express a higher $\left[\mathrm{Cl}^{-}\right]_{\mathrm{i}}$ compared to $\left[\mathrm{Cl}^{-}\right]_{\mathrm{o}}$, GABA acts as an excitatory neurotransmitter. Hence, during CNS development, a switch from excitatory to inhibitory effects of GABA occurs. In the mouse pre-Bötzinger complex (PBC), a brainstem respiratory structure that drives the rhythmic activity of the hypoglossal motoneurons, gramicidin perforated patch-clamp recordings that preserve the physiological $\left[\mathrm{Cl}^{-}\right]_{\mathrm{i}}$ indicate that the reversal potential of $\mathrm{GABA}_{\mathrm{A}} \mathrm{R}$-mediated current $\left(\mathrm{EGABA}_{\mathrm{A}} \mathrm{R}\right.$ that corresponds to $E_{\mathrm{Cl}}$ ) switches from depolarizing to hyperpolarizing within the first postnatal $(\mathrm{P})$ week $\left(\mathrm{EGABA}_{\mathrm{A}} \mathrm{R}\right.$ drops from $-44 \mathrm{mV}$ at P2 to $-71 \mathrm{mV}$ at P4) [42]. Because the resting membrane potential (rmp) for all $\mathrm{PBC}$ neurons was $-56 \mathrm{mV}$, a switch from excitatory to inhibitory effects of GABA is evidenced between P2 and P4. Results obtained from gramicidin perforatepatched HMs are in good agreement with those collected in $\mathrm{PBC}$ neurons, because $E_{\mathrm{Cl}}$ is measured as being $-37 \mathrm{mV}$ in neonates HMs (P2) and $-73 \mathrm{mV}$ in juveniles HMs (P15), but the exact time of the switch remains undetermined between P2 and P15 (rmp of HMs is $-70 \mathrm{mV}$ ) [43]. However, two other studies $[44,45]$ reported that by birth, GABA induces a hyperpolarization of the membrane potential in respiratory medullary neurons and a suppression of respiratory frequency. These studies, which are based on gramicidin perforated-patch clamp recordings, rather indicate that the transition from excitatory to inhibitory effects occurs at approximately E19 but not during post-natal stages in respiratory networks. From a technical point of view, measures of the $\mathrm{GABA}_{\mathrm{A}} \mathrm{R}$-related driving force may be considered with caution because invasive recordings (including perforated patch-clamp) combined with large input resistances of immature neurons may lead to inexact resting membrane potential values, true resting membrane potential values being more hyperpolarized (see [46]).

When does the switch from excitatory to inhibitory effects of GABA occur in spinal MNs? We have showed that there is a shift of $\mathrm{EGABA}_{\mathrm{A}} \mathrm{R}$ toward negative values during the embryonic development of mouse lumbar spinal MNs [47]. Our data demonstrated that until E15.5, $E_{\mathrm{Cl}}$ is above the spike threshold, whereas after E16.5, it drops significantly below spike threshold. During the course of the embryonic development, rmp of mouse spinal MNs remains below the $E_{\mathrm{Cl}}$. However, if $\mathrm{GABA}_{\mathrm{A}} \mathrm{R}$ activation may trigger the firing of MNs until E15.5, after this embryonic developmental stage, such activation, although producing a depolarization, fails to trigger action potentials [47] (Figure 1). Our results indicate that GABA likely exerts a shunting action on mouse spinal MNs after E15.5, as demonstrated in the neonate rat spinal cord [48] and also described in current-clamp 


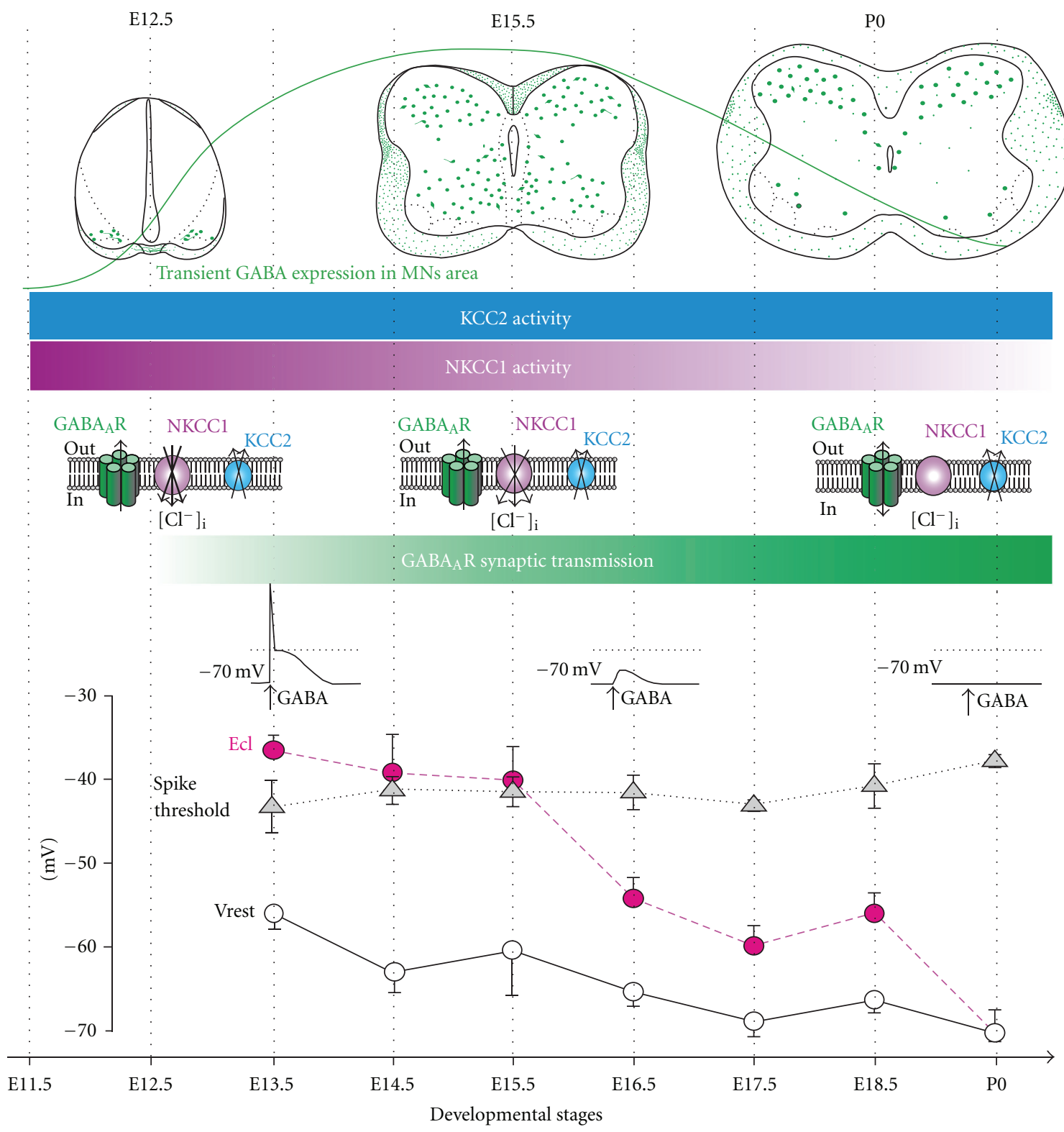

FIGURE 1: Development of the GABA $\mathrm{A}$-mediated inhibitory transmission in mouse lumbar spinal MNs. From top to bottom: schematic drawings (frontal views) depict the transient expression of GABA in spinal ventral interneurons (in green), while horizontal bars indicate the permanent KCC2 (in blue) and transient NKCC1 activity (in violet). The color intensity encodes the level of activity. NKCC1 inactivation combined to KCC2 activity leads to a significant decrease in $\left[\mathrm{Cl}^{-}\right]_{\mathrm{i}}$ and a disappearance of GABA $\mathrm{R}$-mediated excitatory effects. In parallel to the maturation of the chloride cotransporters KCC2 and NKCC1, the spinal cord starts to convey first synaptic activity at E12.5 that is GABAergic (green horizontal bar). Bottom: maturation of the chloride equilibrium potential $\left(E_{\mathrm{Cl}}\right)$, spike threshold and resting membrane potential (Vrest) across the embryonic stages of developmental. Note the drop of $E_{\mathrm{Cl}}$ at E16.5 that accounts for the "shunting" GABA $\mathrm{A}_{\mathrm{A}}$ mediated effect (modified from $[47,56,66]$ ).

experiments by Hubner and collaborators in E18.5 mouse spinal MNs [49]. This shunting depolarizing GABA effect likely persists during postnatal stages even though our experimental measurements indicate that $E_{\mathrm{Cl}}$ reaches MNs rmp at P0 [47]. A recent study based on conventional intracellular recordings clearly demonstrated that the shift from excitatory to inhibitory IPSPs occurs at P4-5 in rat spinal MNs [50]. This was in agreement with intracellular recordings performed by $\mathrm{Wu}$ and collaborators showing much smaller (but still) depolarizing effects of GABA at P0 compared to E16-E18 in rat spinal MNs [51]. Another study, based on gramicidin perforated patch-clamp recordings, indicates that $\mathrm{EGABA}_{\mathrm{A}} \mathrm{R}$ shifts between P5 and P10 in mouse spinal MNs, that is, at a later developmental stage compared to the rat [52]. Hence, further experiments would be needed to precisely determine whether the switch from excitatory to inhibitory effects of GABA really occurs in mouse spinal $\mathrm{MNs}$, and it would be interesting to determine whether an 
oxytocin-driven transient loss of chloride occurs at birth in spinal MNs as described in hippocampal neurons [53].

\section{Transient Expression of GABA in Motoneuronal Region during the Embryonic Life}

Analyzing the maturation of GABA effects in MNs implies that an endogenous GABAergic innervation is present. GABA effects are indeed often tested using local application of exogenous $\mathrm{GABA}$ or $\mathrm{GABA}_{\mathrm{A}} \mathrm{R}$ agonist (i.e., muscimol or isoguvacine) $[42,47]$. It is thus essential to examine the ontogeny of GABA and GABA receptors. The detailed mapping of the GABAergic system has been extensively described in the adult brainstem by in situ hybridization, immunohistochemistry using antibodies directed against GABA or the GAD protein, specifically the $67-\mathrm{kDa}$ isoform (GAD67) [54] or by taking advantage of the GAD67-GFP knock-in mouse [55]. However, to our knowledge, the ontogeny of the GABAergic innervation of brainstem MNs has not been precisely mapped.

We have described the process of embryonic maturation of GABA immunostaining in the mouse spinal cord [56]. Our study indicated that GABA-ir somata are first detected at embryonic day 11.5 (E11.5), exclusively at brachial level, in the ventral horn. By E13.5, the number of GABAergic neurons sharply increases throughout the extent of the ventral horn both at brachial and lumbar level. At E15.5, stained perikarya decrease in number in the ventral gray matter, while GABA-ir fibers are detected contacting MNs. Such a transient expression of GABA immunoreactivity in the spinal ventral horn was also described in the developing rat $[57,58]$ and chick [59].

\section{GABAergic Synaptic Activity: A Predominant Neurotransmission in MNs at Early Developmental Stages}

From a functional point of view, GABA effects differ according to the developmental stage. At early stages, excitatory GABA effects contribute, with cholinergic inputs, to the genesis of spontaneous network activity in the chick [60], mouse $[61,62]$ and rat $[63,64]$ spinal cord. At these early stages, MNs are still growing to their peripheral targets and the GABA-mediated spontaneous activity is required for correct motor axon guidance [65]. We have recently showed that first synaptic activity occurs at E12.5 in mouse spinal MNs [66] when the GABAergic phenotype starts to be largely expressed by interneurons located in the ventral gray matter [56]. GABAergic synaptic activity then increases in frequency and coexists with a glycinergic synaptic transmission [66]. In most immature CNS regions, GABA signaling is established before glutamatergic transmission, suggesting that GABA is the principal excitatory transmitter during early development [30]. In the spinal cord, pharmacological approaches performed while recording spontaneous activity showed as well that GABA generates, with acetylcholine [67], the earliest spontaneous motor activity and then glutamate interfere [64]. Our analysis also revealed that the glutamatergic synaptic transmission mainly develops in the embryonic spinal cord after the GABAergic one at around E14.5 (personal observation). Hence, GABA appears as a sort of automated expressed first ubiquitous signal, and then and only then does the adult behavior resumes. Interestingly, it has been shown that the glutamatergic transmission regulates the strength of GABAergic synapses [68].

If the synaptic transmission develops during the embryonic life in spinal MNs, it maturates during postnatal stages and a developmental shift from primarily long-duration GABAergic mIPSCs to short-duration glycinergic mIPSCs occurs after birth in rat MNs [69].

At E15.5 in the rat, commissural GABAergic connections mediate synchronous excitatory action on rhythm-generating networks in the ventral spinal cord, while at E18.5, these GABAergic commissural connections are responsible for reciprocal inhibition during left and right alternation [70]. Interestingly, at E20.5 in rat embryo, these inhibitory commissural inputs become mediated by glycine and not anymore by GABA [70]. These results that take over the primordial role of $\mathrm{GABA}_{\mathrm{A}} \mathrm{R}$ for ensuring spontaneous activity and then reciprocal inhibition between left and right sides of the ventral spinal cord may explain why such a huge expression of GABA is detected in ventral spinal networks at E15.5, in the mouse [56]. At postnatal developmental stages, when commissural connections are mostly mediated by glycine [71-74], GABAergic inhibition has been shown to regulate the onset and duration of neurochemically induced locomotor activity [75].

\section{Ontogeny of KCC2 and NKCC1 Immunoreactivity}

The switch from excitatory to inhibitory $\mathrm{GABA}_{\mathrm{A}} \mathrm{R}$-related effects is closely related to the lowering of $\left[\mathrm{Cl}^{-}\right]_{\mathrm{i}}$ during the course of the development. This latter mainly relies on the differential ontogenic expression of the $\mathrm{Na}^{+} / \mathrm{K}^{+} / 2 \mathrm{Cl}^{-}$cotransporter isoform 1 (NKCC1), which uptakes chloride ions [76-78], and the neuronal $\mathrm{K}^{+} / \mathrm{Cl}^{-}$cotransporter type 2 (KCC2) [79], which extrudes chloride ions [49, 80]. However, other exchangers can control the chloride gradient as the anion $\left(\mathrm{Cl}^{-}-\mathrm{HCO}_{3}{ }^{-}\right)$exchangers, either $\mathrm{Na}^{+}$- independent (AE) or $\mathrm{Na}^{+}$-driven (NDCBE also called NDAE) [81] (NCBE) [82]. AE mediates influx of $\mathrm{Cl}^{-}$while exporting $\mathrm{HCO}_{3}{ }^{-}$, these exchanges being triggered by intracellular alkalinisation. NDCBE, known as an acid extruder (extrudes $\mathrm{H}^{+}$), moves $\mathrm{Cl}^{-}$out in exchange of $\mathrm{HCO}_{3}{ }^{-}$, driven by the $\mathrm{Na}^{+}$gradient $[83,84]$. NCBE also lowers $\left[\mathrm{Cl}^{-}\right]_{\mathrm{i}}\left(\right.$ and $\left.\left[\mathrm{H}^{+}\right]_{\mathrm{i}}\right)$ while importing $\mathrm{Na}^{+}$and $\mathrm{HCO}_{3}{ }^{-}[82,85]$.

It is generally accepted that early in development, NKCC1 is predominant and, therefore, maintains a high $\left[\mathrm{Cl}^{-}\right]_{\mathrm{i}}$, while at later stages, NKCC1 vanishes, and KCC2 develops, lowering intracellular chloride levels [86-88]. In spinal cord MNs, it was shown that the expression of KCC2 transcripts parallels neuronal differentiation during the embryonic life and preceded the decline of the $\mathrm{GABA}_{\mathrm{A}} \mathrm{R}$ reversal potential $\left(\mathrm{EGABA}_{\mathrm{A}} \mathrm{R}\right)$ [52]. Thus, the relationship between KCC2, 
NKCC1, and EGABA $A_{A} R$ during the course of the embryonic development remained an open question. We addressed this question in a previous study [47] and found that KCC2 immunoreactivity (KCC2-ir) can be detected in MNs area as early as E11.5, confirming the Stein's study [52], when NKCC1 is also largely expressed. At E14.5, KCC2 is largely present in the ventral gray matter and at later stages this protein keeps stable. At E11.5, a dense NKCC1 labelling is detected throughout the ventral grey matter. Thus, our data indicated that the main drop of $E_{\mathrm{Cl}}$ occurring at E16.5 is likely dependant on a reduction of the NKCC1 efficacy rather than a later expression of KCC2. In the rat, Stil and coworkers investigated the expression of KCC2 and NKCC1 in the ventral horn of the spinal cord from E17 to P20 and found that the expression of KCC2 increases significantly, while the expression of NKCC1 decreases during postnatal life when the shift from depolarizing to hyperpolarizing IPSPs occurs (at P4-P5) [50].

It must be mentioned that analyzing the shift from depolarizing to hyperpolarizing effects of GABA in spinal MNs by taking into account only KCC2 and NKCC1 may be simplistic, because the anion exchangers $\mathrm{AE}$ has been clearly demonstrated as accumulating chloride in immature chick MNs [89]. Hence, the expression of inhibitory GABA effects likely also relies on the reduction of $\mathrm{AE}$ in addition to NKCC1. Also, NCBE that is expressed as early as E14.5 in the mouse SC [90] may play an important role in lowering $\left[\mathrm{Cl}^{-}\right]_{\mathrm{i}}$.

On the whole, even though likely oversimplified, Figure 1, that is based on our data, illustrates the ontogeny of the GABAergic inhibitory synaptic transmission in parallel to the activity of the two main cotransporters KCC2 and NKCC1. It must be noted that the transient maximum expression of GABA in ventral motor network precedes the drop of $E_{\mathrm{Cl}}$.

\section{Ontogenic Changes of the GABAergic Receptors in MNs}

$\mathrm{GABA}_{\mathrm{A}} \mathrm{R}$ and $\mathrm{GABA}_{\mathrm{C}} \mathrm{R}$ as glycine, nicotinic acetylcholine, and 5-hydroxytryptamine type 3 receptors belong to the cystein-loop receptor family. They are both pentameric assemblies of subunits, each subunits being characterized by extracellular $\mathrm{N}$ and $\mathrm{C}$ terminals and by four transmembrane domains (TM1-TM4), the domain TM2 forming the anionic channel pore [91]. $\mathrm{GABA}_{\mathrm{A}}$ Rs are composed of a large variety of different subunits, sixteen $\mathrm{GABA}_{\mathrm{A}} \mathrm{Rs}$ subunits being cloned so far $(\alpha 1-6, \beta 1-3, \gamma 1-3, \delta, \varepsilon, \theta$, and $\pi)$ and three $(\rho 1-3)$ for $\mathrm{GABA}_{C} \mathrm{R}[92,93]$. The number of $\mathrm{GABA}_{\mathrm{A}} \mathrm{R}$ subunits is also theoretically increased by alternative splicing but only a dozen of subunit combinations have been detected so far [93]. The agonist binding site is carried mainly by $\alpha$ subunits, while $\gamma$ subunits are responsible for linking $\mathrm{GABA}_{\mathrm{A}}$ Rs to the postsynaptic cytoskeleton. The most abundantly expressed $\mathrm{GABA}_{\mathrm{A}} \mathrm{R}$ in the adult CNS has a stoichiometry of $2 \alpha, 2 \beta$, and $1 \gamma 2$ subunit. In addition $\mathrm{GABA}_{\mathrm{A}} \mathrm{R}$ subunit combination varies according to the synaptic and extrasynaptic location of this receptor. For example, $G_{A B A}$ Rs containing the $\delta$ subunit or the $\alpha 5$ subunit cannot accumulate at postsynaptic site, likely because they cannot anchor to postsynaptic scaffold protein complex [93-95]. Remarkably, the extrasynaptic $\mathrm{GABA}_{\mathrm{A}}$ Rs containing the $\delta$ subunit $\left(\alpha \beta \delta \mathrm{GABA}_{\mathrm{A}} \mathrm{R}\right)$ have a higher apparent affinity for GABA and desensitize more slowly and less extensively than postsynaptic $\mathrm{GABA}_{\mathrm{A}} \mathrm{Rs}$ containing the $\beta$ and/or the $\gamma$ subunits [96], while $\mathrm{GABA}_{\mathrm{A}}$ Rs containing the $\alpha 5$ subunit display a reduction in their desensitization kinetics when compared with receptors containing other $\alpha$ subunits [97].

In the adult lumbar rat spinal cord, only $\alpha 2, \alpha 3, \beta 3$, and $\gamma 2$ mRNAs are expressed at significant levels, the $\alpha 3$, $\beta 3$ and $\gamma 2$ transcripts being present in many neurons throughout the Rexed laminae, whereas the $\alpha 2$ mRNA is restricted to motor neurons and adjacent cells [98]. A high expression level of the $\alpha 1$ and the $\alpha 2$ subunits is detected using immunohistochemistry in the adult rat oculomotor trochlear nuclei, the hypoglossal nucleus, and the dorsal nucleus of the vagus [99]. Interestingly, the motor trigeminal nucleus mainly expresses the $\alpha 2$ subunits, while $\alpha 5$ and $\beta 2 / 3$ are poorly present in these CNS areas and the $\delta$ subunit is undetectable [99]. A recent immunohistochemical study, performed in human brainstem and cervical spinal cord, shows roughly similar results [100]. In this study, Waldvogel et al. did not analyze the expression of $\alpha 4-\alpha 6$ subunits and $\delta$ subunits, but they showed that $\alpha 1, \alpha 2, \alpha 3, \beta 2 / 3$, and $\gamma 2$ $\mathrm{GABA}_{\mathrm{A}} \mathrm{R}$ subunits are largely detected in the brainstem motoneuron nuclei and in the lamina IX as well as, in less extend, in the lamina $X$ of the cervical spinal cord [100]. However, their data, collected from human brain, differ from Fritschy's group results obtained from rat tissue. Indeed, Waldvogel et al. find a high expression of $\alpha 1, \alpha 2, \alpha 3$, and $\beta 2 / 3$ subunits in the motor trigeminal nucleus, while the $\gamma 2$ subunit was poorly expressed [100]. This could reflect differences in $\mathrm{GABA}_{\mathrm{A}} \mathrm{R}$ subunit expression between species. However, because these two studies are based on a semi quantitative analysis of immunostaining, at a macroscopic level, discrepancies must be taken with caution. Effectively, it is well known that immunostaining, particularly for $\mathrm{GABA}_{\mathrm{A}} \mathrm{R}$ subunits, can strongly vary depending on the fixation procedure $[101,102]$.

From a developmental point of view, little is known about changes in $\mathrm{GABA}_{\mathrm{A}} \mathrm{R}$ subunit expression during spinal cord MNs development. In the rat cervical spinal cord, the $\alpha 6$ and $\delta$ subunits mRNAs are not detectable at all ages tested (from E12 to adult). During the ontogeny, as demonstrated for GABA [56, 57], subunits mRNA expression emerges along a ventrodorsal gradient. In fact, $\alpha 2, \alpha 3, \alpha 5, \beta 2, \beta 3$, $\gamma 2$, and $\gamma 3$ subunits emerge in presumptive MNs at E12E13 and then can be detected in more dorsal regions [103]. A synchronized peak of $\alpha 2, \alpha 3, \beta 2, \beta 3, \gamma 2$, and $\gamma 3$ subunits mRNAs is detected at neonatal stages. In the adult rat cervical spinal cord, $\mathrm{GABA}_{\mathrm{A}} \mathrm{R} \alpha 1, \alpha 4, \alpha 5, \beta 1-2, \gamma 1$, and $\gamma 3$ subunit mRNAs are found only in relatively few cells scattered in the gray matter, whereas mature MNs exhibit $\alpha 2 \beta 3 \gamma 2$ transcripts [103]. Thus, contrary to that observed for glycine receptors [104], there is no obvious switch in GABA subunit expression during prenatal and postnatal development of MNs. Interestingly, the $\alpha 3$ mRNA level observed at early 
developmental stage in the lateral motor column decreases around birth and was no longer detected in the adult [103]. In the hypoglossal nuclei, indirect proofs based on immunochemistry favor a switch from $\alpha 1$ to $\alpha 2$ subunits, during prenatal development [105]. As mentioned above, the $\alpha 1$ and $\alpha 2$ $\mathrm{GABA}_{\mathrm{A}} \mathrm{R}$ subunits, together with the $\gamma 2 \mathrm{GABA}_{\mathrm{A}} \mathrm{R}$ subunit, are the main $\mathrm{GABA}_{\mathrm{A}} \mathrm{R}$ subunits expressed in the hypoglossal nucleus of the adult rat [99]. Assuming that $\gamma 2 \mathrm{GABA}_{\mathrm{A}} \mathrm{R}$ clusters that do not colocalize with $\alpha 1 \mathrm{GABA}_{\mathrm{A}} \mathrm{R}$ clusters reflect the presence of $\mathrm{GABA}_{\mathrm{A}} \mathrm{R}$ containing $\alpha 2$ subunits, Muller and collaborators concluded for an increase in the proportion of $\mathrm{GABA}_{\mathrm{A}} \mathrm{R}$ containing $\alpha 2 \mathrm{GABA}_{\mathrm{A}} \mathrm{R}$ subunits [105]. However, this is in apparent contradiction to other studies showing that the $\alpha 2 \mathrm{GABA}_{\mathrm{A}} \mathrm{R}$ subunits are expressed early in development and are progressively replaced by $\alpha 1 \mathrm{GABA}_{\mathrm{A}} \mathrm{R}$ subunit in many brain areas [106]. A further quantitative immunohistochemical analysis of the developmental changes in the proportion of $\alpha 2$ and $\alpha 1 \mathrm{GABA}_{\mathrm{A}} \mathrm{R}$ subunits in the hypoglossal nucleus is thus required in order to verify that developmental maturation processes of $\mathrm{GABA}_{\mathrm{A}} \mathrm{Rs}$ can vary between CNS areas.

If it is now clearly demonstrated that $\mathrm{GABA}_{\mathrm{A}} \mathrm{R}$ subunits may evolve during development and vary according to brain areas, few data are available concerning the cellular location of these subunits on a single MNs. Using immunocytochemistry and confocal microscopy, Lorenzo et al. compared the subcellular patterns of expression of the main $\mathrm{GABA}_{\mathrm{A}} \mathrm{R}$ subunits $\left(\mathrm{GABA}_{\mathrm{A}} \mathrm{R} \alpha 1, \alpha 2, \alpha 3\right.$, and $\left.\alpha 5\right)$ in the somatic versus dendritic compartments of rat abducens MNs [107] and revealed a differential organization of $\mathrm{GABA}_{\mathrm{A}} \mathrm{R}$ subunits. They found that $\mathrm{MNs}$ somata contain only $\mathrm{GABA}_{\mathrm{A}} \mathrm{R} \alpha 1$, while both $\mathrm{GABA}_{\mathrm{A}} \mathrm{R} \alpha 1$ and $\mathrm{GABA}_{\mathrm{A}} \mathrm{R} \alpha 3$ are detected on dendrites [107].

\section{Maturation of the GABAergic System on Motoneuron in Normal and Pathological Conditions: Mixed GABA/glycine Synapses and Mismatch between Pre- and Postsynaptic Elements}

During the first 3 weeks of rodent postnatal development, inhibitory synaptic transmission changes in multiple ways that differ depending on brain areas. Electrophysiology and immunocytochemistry suggest that the respective contribution of the glycinergic and GABAergic transmission to the overall inhibitory message received by postsynaptic neurons may vary during the developmental period. For example, a developmental switch from a predominant GABAergic to main glycinergic neurotransmission occurs in the lumbar spinal cord [69] and in the lateral superior olive of young rodents $[108,109]$, while GABAergic neurotransmission dominates in developing collicular neurons [110] (Figure 2(a)).

As first demonstrated in neonatal spinal MNs, glycine and GABA can be coreleased from the same presynaptic vesicle resulting in a mixed glycinergic/GABAergic synaptic event [111]. Mixed inhibitory synapses have also been functionally identified in MNs of the hypoglossal nucleus [112, $113]$, but mixed synapses are not particular to inhibitory input on MNs, because they are also described on spinal interneurons $[114,115]$. If mixed inhibitory synapses appear to reflect an intermediate stage of maturation of glycinergic synapses, it must be noted that although the proportion of mixed synapses decreases during development in Renshaw cells and other spinal cord interneurons [116], mixed inhibitory synapses remain functional in the adult $[114,116]$. This is also the case in abducens MNs during rat postnatal development: before birth, only GABAergic axon terminals develop, whereas mixed GABA/glycine axon terminals appear at birth, and their number increases during the first postnatal week [117].

Functional mixed inhibitory synapses have also been described in rat HMs [112, 113]. However, a complete morphofunctional study of the development of inhibitory synapse on the mouse HMs, between P3-P5 and P15, revealed that the developmental shift from glycinergic/GABAergic to pure glycinergic neurotransmission depends mainly on the maturation of the presynaptic elements, while postsynaptic GlyRs and $\mathrm{GABA}_{\mathrm{A}}$ Rs remain associated at the same postsynaptic density at all age tested. Effectively, although miniature inhibitory postsynaptic currents (mIPSCs) are mainly glycinergic and mixed glycinergic/GABAergic at P3-P5 and then predominantly glycinergic at P15 (Figures 2(b) and 2(c)), postsynaptic GlyRs and $\mathrm{GABA}_{\mathrm{A}}$ Rs remain associated at the same postsynaptic density at all age tested [118]. In addition, because many GABAergic synapses are unlikely to contain postsynaptic $\mathrm{GABA}_{\mathrm{A}}$ Rs yet, it was supposed that they represent newly formed "nonfunctional" GABAergic synaptic contacts, as previously observed in the cerebellum $[119,120]$. It is, however, unclear whether such a discrepancy between the pre- and the postsynaptic element also occurs in other CNS area during development, but it must be noted that a similar maturation process of the inhibitory presynaptic terminals was also observed in neurons of the rat lateral superior olive [109]. Moreover, postsynaptic $\mathrm{GABA}_{\mathrm{A}} \mathrm{Rs}$ facing presynaptic terminals that do not release GABA have also been reported in the spinal cord and brain neuropil in culture [121-125]. Such a mismatch between the pre- and the postsynaptic element of inhibitory synapses was also observed in the adult Renshaw cells of the rat spinal cord [114]. In that case, it was proposed that GABAergic presynaptic terminals could face postsynaptic GlyR clusters [114]. Altogether, these data suggest that the maturation of inhibitory synapses rather results from a differential regulation of the GlyT2 and GAD65 expression at the level of a single synaptic terminal but not from a redistribution of GlyRs and $\mathrm{GABA}_{\mathrm{A}}$ Rs at postsynaptic site.

Our data from the hypoglossal nucleus also suggest that pre- and postsynaptic elements mature independently [118]. However, a more recent study performed on spastic (SPA) mice, a model for hyperekplexia, argues against this hypothesis [126]. SPA mice display an insertion of an LINE-1 transposable element into the gene coding for the GlyR $\beta$ subunit, which results in a truncated protein that impairs accumulation of GlyRs at postsynaptic sites and leads to a strong dysfunction of glycinergic synaptic transmission $[127,128]$. In C57BL/6J strain, SPA mice which express a lower amount of GlyR $\beta$ subunits die 2-3 weeks after birth 

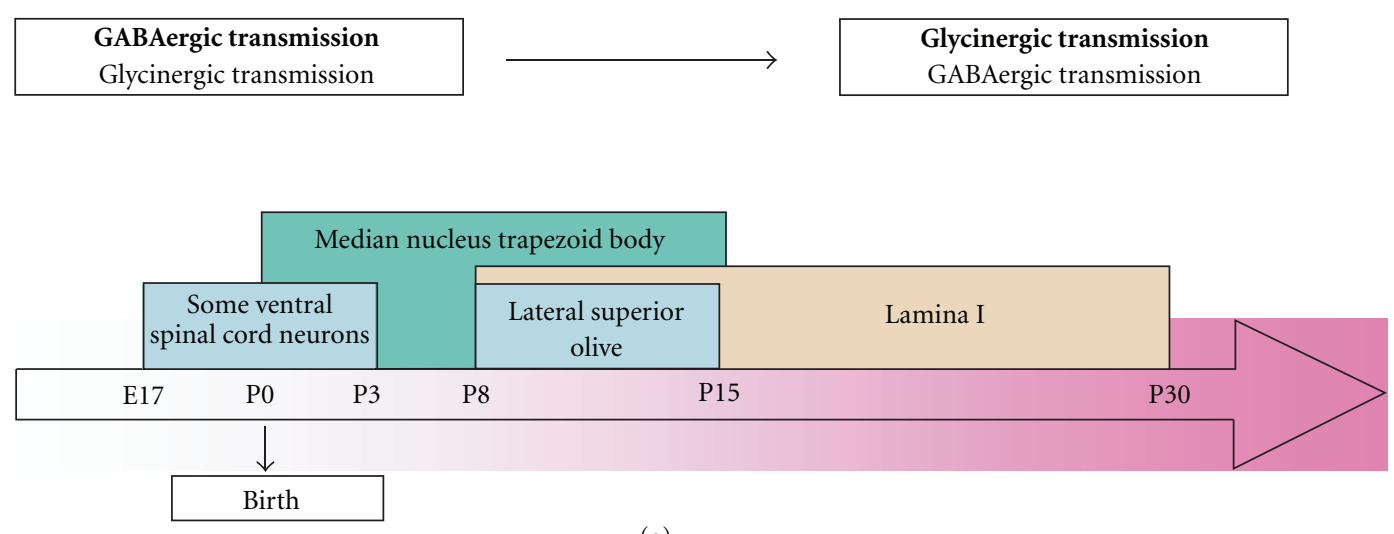

(a)
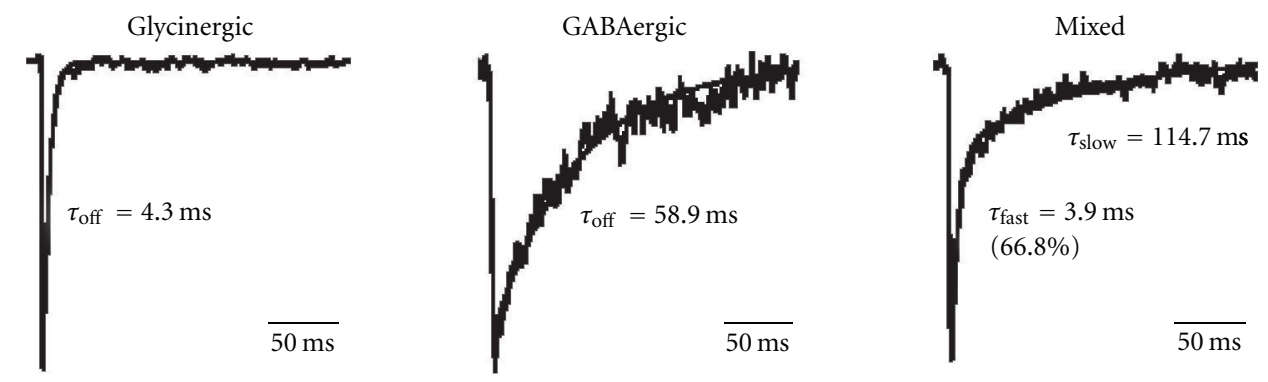

(b)

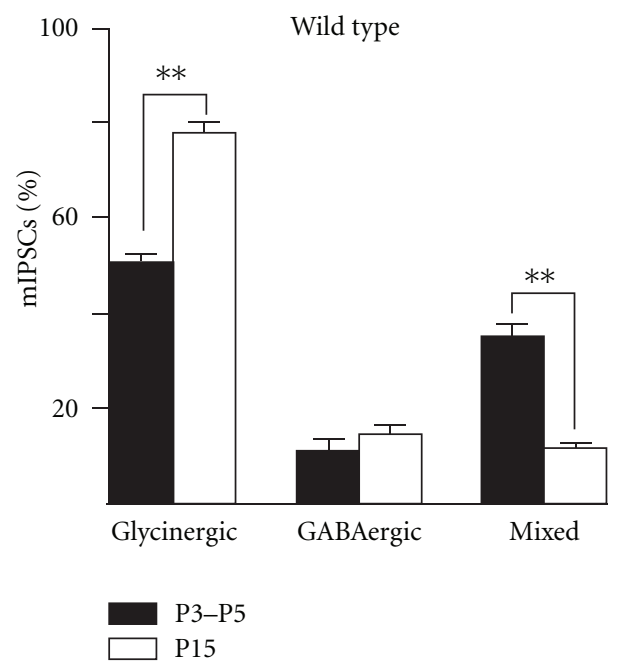

(c)

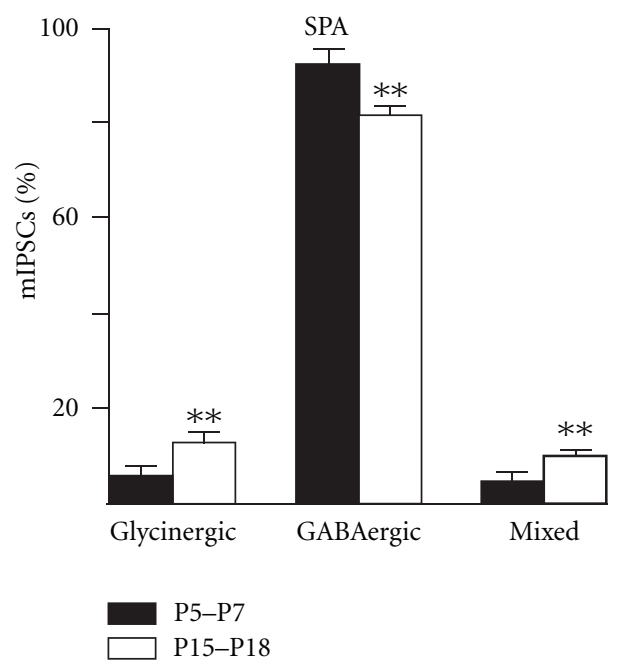

(d)

FIgURE 2: (a) Developmental changes in the proportions of GABAergic and glycinergic synaptic activity in various areas of the central nervous system. (b) Examples of individual glycinergic (left) GABAergic (middle) and mixed (right) miniature inhibitory postsynaptic currents (mIPSCs) recorded in a hypoglossal motoneuron at P15, in the presence of tetrodotoxin (a blocker of voltage-gated sodium channels). Note the slower decay phase of the GABAergic mIPSC compared to the glycinergic mIPSC. Decay phase of GABAergic and glycinergic events is better fitted with a single exponential function, while a double exponential function is required to fit the decay phase of mixed events. (c) Relative proportions of glycinergic, GABAergic and mixed mIPSCs at P3-P5 (black bars) and at P15 (white bars) in wild-type mice. (d) Relative proportions of glycinergic, GABAergic and mixed miniature postsynaptic events at P5-P7 (black bars) and at P15-P18 (white bars) in SPA mice. (Adapted from $[118,126]$ ).

[129], suggesting that GABAergic compensation does not necessarily take place. It was first hypothesized that the progressive postnatal developmental lost of GABAergic presynaptic terminals that normally occurs in wild-type mice due to a switch to glycinergic terminals [118] could explain the progressive impairment of inhibitory synaptic activity and thus the lethality of this mutation. But surprisingly, in opposition to our observations made in wild-type animal, the 
inhibitory synaptic activity is mainly GABAergic in SPA mice (Figure 2(d)): a developmental decrease in glycinergic presynaptic terminals occurs, while the density of GABAergic presynaptic terminals increases [126]. In addition, the proportion of inhibitory presynaptic terminals facing $G_{A B A} R s$ significantly increases during postnatal development in $\mathrm{HMs}$ of SPA mice. It must, however, be noted that many GABAergic synaptic boutons face diffuse $\mathrm{GABA}_{\mathrm{A}}$ Rs staining, which contrasts to the situation observed in wild-type animal which most of the presynaptic terminals face aggregated $G_{A B A}$ Rs. It is, thus, likely that GABAergic synapses are less efficient in SPA mice than in wild type [126]. Also, because SPA mice cannot survive, these results indicate that GABAergic neurotransmission does not compensate for defects in GlyR postsynaptic aggregation in this hyperekplexia model. They also suggest, contrary to that previously hypothesized [118], that a crosstalk exists between postsynaptic and presynaptic elements, leading to the developmental regulation of the presynaptic terminal neurotransmitter content that could be related to a downregulation of GlyT2 expression and an upregulation of GAD65 expression at inhibitory presynaptic terminals depending on the level of postsynaptic GlyR aggregation.

Alteration of $\mathrm{GABA}_{\mathrm{A}} \mathrm{R}$ and GlyR expression was also analyzed in MNs vulnerable and resistant to amyotrophic lateral sclerosis (ALS) [41]. Because a reduced level of expression of the $\mathrm{GABA}_{\mathrm{A}} \mathrm{R} \alpha 1$ subunit mRNA has been shown in neurons of the motor cortex of patients with ALS [130], Lorenzo et al. investigated, using a quantitative immunohistochemical study, the possibility that $\mathrm{GABA}_{\mathrm{A}} \mathrm{R}$ and GlyR might be expressed differentially in ALS-vulnerable and ALSresistant brainstem MNs in an ALS rat model [41]. Indeed, MNs controlling eye movements and bladder contraction are surprisingly unaffected (they are ALS-resistant) during terminal stages of ALS, while other MNs underlie an invariably fatal degeneration (they are ALS-vulnerable) [131]. Their main hypothesis was a reduction in $\mathrm{GABA}_{\mathrm{A}} \mathrm{R}$ and GlyR expression in vulnerable MNs, which could account for an alteration of the inhibition and hence for an amplification of the glutamatergic synaptic activity onto these MNs, an excessive excitatory transmission being known to be detrimental. Interestingly, Lorenzo et al. showed a differential expression of $\mathrm{GABA}_{\mathrm{A}} \mathrm{R}$ (and GlyR) in brainstem ALS-resistant oculomotor (III), trochlear (IV), abducens (VI) versus ALS-vulnerable MNs trigeminal (V), facial (VII), hypoglossal (XII) [41]. They demonstrated that $\mathrm{GABA}_{\mathrm{A}} \mathrm{R}$ in ALSvulnerable MNs mostly express $\alpha 2$ subunits while $G_{A B A_{A}} R$ in ALS-resistant MNs are $\alpha 1$ subunits enriched. They also showed that ALS-resistant MNs contain a larger proportion of extrasynaptic $\mathrm{GABA}_{\mathrm{A}} \mathrm{R}$ clusters than ALS-vulnerable MNs. Because extrasynaptic $\mathrm{GABA}_{A} \mathrm{R}$ are activated by GABA spillover from synapses [132-134] and mediate a tonic inhibition that plays a crucial role in regulating neuronal excitability [135], the authors hypothesized that the presence of extrasynaptic $\mathrm{GABA}_{\mathrm{A}} \mathrm{R}$ in ALS-resistant MNs could protect these neurons from excessive depolarization by abnormal glutamate release. Their data demonstrated that the rate of occurrence of extrasynaptic $\mathrm{GABA}_{\mathrm{A}} \mathrm{R}$ clusters was approximately twice as high in ALS-resistant as in ALS-vulnerable
MNs, but more experiments are necessary to determine to what extend this difference accounts for the vulnerability of MNs, as for example by manipulating extrasynaptic $\mathrm{GABA}_{\mathrm{A}} \mathrm{R}$ expression in specific MNs. On the contrary, recent reports show that glycinergic innervation but not GABAergic innervation of spinal MNs is deficient in the ALS mouse model expressing the mutant form of human superoxide dismutase-1 with G93A substitution (SOD1 ${ }^{\mathrm{G} 93 \mathrm{~A}}$ ) $[136,137]$. The authors examined, using whole-cell patch-clamp recordings, GlyR-mediated currents in cultured spinal MNs from this ALS mouse model. They found that glycine-evoked current density was significantly smaller in the SOD1 MNs compared to control. However, they did not find any change in GABAergic synaptic activity. This alteration in glycinergic synaptic activity is likely to be due to a lower GlyR $\alpha 1$ subunit mRNA expression in SOD1 ${ }^{\mathrm{G} 93 \mathrm{~A}} \mathrm{MNs}$ [137]. These results suggest that a selective alteration in GlyR expression can partly account for an alteration of inhibitory synapse efficacy in MNs early in the disease process of ALS, with SOD1G93A substitution at least. But these data obtained from GlyR expression in this ALS mouse model do not demonstrate, as data regarding $\mathrm{GABA}_{\mathrm{A}} \mathrm{R}$ expression, that a reduction of receptor subunit expression can effectively account for MNs vulnerability in ALS. Again, more experiment is necessary to resolve this issue.

Finally, these results on $\mathrm{GABA}_{\mathrm{A}} \mathrm{R}$ or GlyRs expression in ALS could be complementary rather than contradictory if one supposes that the expression of the different GlyR and $G_{A B A} R$ subunits can be region specific. For example, $\mathrm{GABA}_{\mathrm{A}} \mathrm{R} \alpha 1$ subunit is poorly expressed in the spinal cord compared to more central region [103], and it is important to note that glycinergic and GABAergic synapses control MNs development in a region-specific manner during programmed cell death as exemplified by data obtained in gephyrin-deficient mice that lack all postsynaptic GlyRs and some $\mathrm{GABA}_{\mathrm{A}} \mathrm{R}$ clusters [138]. In these gephyrin-deficient mice, there is a reduced respiratory MN survival and decreased innervation of the diaphragm, whereas limb-innervating MNs show increased survival and increased innervation of their target muscles [138].

\section{Concluding Remarks}

If GABAergic interneurons constitute only $17 \%-20 \%$ of the neurons in the brain [139], their primordial role in the maintenance of a good balance in neuronal connections is obvious. $\mathrm{GABA}_{\mathrm{A}} \mathrm{R}$ activation is likely to play an important role on spinal cord and brainstem MNs development as well as during pathological conditions, but it is unclear to what extend such a diversity leading to functionally different $\mathrm{GABA}_{\mathrm{A}} \mathrm{Rs}$ is important for a proper development of functional locomotor networks and to what extend a defect in a subunit expression can impact neuronal survival during development and in pathological condition as in ALS. For example, it will be of interest to determine to what extend the expression of $\alpha 2 \mathrm{GABA}_{\mathrm{A}} \mathrm{Rs}$ instead of $\alpha 1$ is important for neuronal development. This can be done using genetic tools as the knock in technique by substituting $\alpha 2$ expression 
by $\alpha 1$. Another unknown mechanism that must be determined is the communication pathway between GABAergic/ glycinergic pre-synaptic neurons and post-synaptic receptors. Thus, it would be worthy to examine changes in the presynaptic GABAergic and/or glycinergic phenotype, during development or in pathological conditions, when a post-synaptic receptor type is missing or altered.

\section{Acknowledgment}

The authors are grateful to Dr. Evelyne Sernagor (Newcastle University Medical School, UK) for helping to prepare the paper.

\section{References}

[1] A. Rozzo, M. Armellin, J. Franzot, C. Chiaruttini, A. Nistri, and E. Tongiorgi, "Expression and dendritic mRNA localization of $\mathrm{GABA}_{C}$ receptor $\rho 1$ and $\rho 2$ subunits in developing rat brain and spinal cord," European Journal of Neuroscience, vol. 15, no. 11, pp. 1747-1758, 2002.

[2] U. Misgeld, M. Bijak, and W. Jarolimek, "A physiological role for $\mathrm{GABA}_{\mathrm{B}}$ receptors and the effects of baclofen in the mammalian central nervous system," Progress in Neurobiology, vol. 46, no. 4, pp. 423-462, 1995.

[3] D. M. Kullmann, A. Ruiz, D. M. Rusakov, R. Scott, A. Semyanov, and M. C. Walker, "Presynaptic, extrasynaptic and axonal $\mathrm{GABA}_{\mathrm{A}}$ receptors in the CNS: where and why?" Progress in Biophysics and Molecular Biology, vol. 87, no. 1, pp. 33-46, 2005.

[4] S. Kirischuk, J. Akyeli, R. Iosub, and R. Grantyn, "Pre- and postsynaptic contribution of $\mathrm{GABA}_{C}$ receptors to GABAergic synaptic transmission in rat collicular slices and cultures," European Journal of Neuroscience, vol. 18, no. 4, pp. 752-758, 2003.

[5] S. E. Clark, M. Garret, and B. Platt, "Postnatal alterations of GABA receptor profiles in the rat superior colliculus," Neuroscience, vol. 104, no. 2, pp. 441-454, 2001.

[6] M. G. Erlander, N. J. Tillakaratne, S. Feldblum, N. Patel, and A. J. Tobin, "Two genes encode distinct glutamate decarboxylases," Neuron, vol. 7, no. 1, pp. 91-100, 1991.

[7] D. F. Bu, M. G. Erlander, B. C. Hitz et al., "Two human glutamate decarboxylases, $65-\mathrm{kDa}$ GAD and $67-\mathrm{kDa} \mathrm{GAD}$, are each encoded by a single gene," Proceedings of the National Academy of Sciences of the United States of America, vol. 89, no. 6, pp. 2115-2119, 1992.

[8] M. H. Brilliant, G. Szabo, Z. Katarova et al., "Sequences homologous to glutamic acid decarboxylase cDNA are present on mouse chromosomes 2 and 10," Genomics, vol. 6, no. 1, pp. 115-122, 1990.

[9] P. Varju, Z. Katarova, E. Madarasz, and G. Szabo, "GABA signalling during development: new data and old questions," Cell and Tissue Research, vol. 305, no. 2, pp. 239-246, 2001.

[10] G. Szabo, Z. Katarova, and R. Greenspan, "Distinct protein forms are produced from alternatively spliced bicistronic glutamic acid decarboxylase mRNAs during development," Molecular and Cellular Biology, vol. 14, no. 11, pp. 7535-7545, 1994.

[11] P. Varju, Z. Katarova, E. Madarász, and G. Szabo, "Sequential induction of embryonic and adult forms of glutamic acid decarboxylase during in vitro-induced neurogenesis in cloned neuroectodermal cell-line, NE-7C2," Journal of Neurochemistry, vol. 80, no. 4, pp. 605-615, 2002.

[12] T. Behar, W. Ma, L. Hudson, and J. L. Barker, "Analysis of the anatomical distribution of GAD mRNA encoding truncated glutamic acid decarboxylase proteins in the embryonic rat brain,” Developmental Brain Research, vol. 77, no. 1, pp. 7787, 1994.

[13] Z. Katarova, G. Sekerkova, S. Prodan, E. Mugnaini, and G. Szabo, "Domain-restricted expression of two glutamic acid decarboxylase genes in midgestation mouse embryos," Journal of Comparative Neurology, vol. 424, no. 4, pp. 607$627,2000$.

[14] W. Ma, T. Behar, L. Chang, and J. L. Barker, "Transient increase in expression of GAD65 and GAD67 mRNAs during postnatal development of rat spinal cord," Journal of Comparative Neurology, vol. 346, no. 1, pp. 151-160, 1994.

[15] C. C. Hsu, K. M. Davis, H. Jin et al., "Association of Lglutamic acid decarboxylase to the 70-kDa heat shock protein as a potential anchoring mechanism to synaptic vesicles," Journal of Biological Chemistry, vol. 275, no. 27, pp. 2082220828, 2000.

[16] J. M. Lauder, J. Liu, L. Devaud, and A. L. Morrow, "GABA as a trophic factor for developing monoamine neurons," Perspectives on Developmental Neurobiology, vol. 5, no. 2-3, pp. 247-259, 1998.

[17] L. Ziskind-Conhaim, "Physiological functions of GABAinduced depolarizations in the developing rat spinal cord," Perspectives on Developmental Neurobiology, vol. 5, no. 2-3, pp. 279-287, 1998.

[18] E. Sernagor, F. Chabrol, G. Bony, and L. Cancedda, "GABAergic control of neurite outgrowth and remodeling during development and adult neurogenesis: general rules and differences in diverse systems," Frontiers in Cellular Neuroscience, vol. 4, no. 11, 11 pages, 2010.

[19] R. Lujan, R. Shigemoto, and G. Lopez-Bendito, "Glutamate and GABA receptor signalling in the developing brain," Neuroscience, vol. 130, no. 3, pp. 567-580, 2005.

[20] K. A. Dave and A. Bordey, "GABA increases $\mathrm{Ca}^{2+}$ in cerebellar granule cell precursors via depolarization: implications for proliferation," IUBMB Life, vol. 61, no. 5, pp. 496-503, 2009.

[21] X. Leinekugel, I. Khalilov, H. McLean et al., "GABA is the principal fast-acting excitatory transmitter in the neonatal brain," Advances in Neurology, vol. 79, pp. 189-201, 1999.

[22] G. Lopez-Bendito, R. Shigemoto, A. Kulik, O. Paulsen, A. Fairen, and R. Lujan, "Expression and distribution of metabotropic GABA receptor subtypes $G_{A B A} R 1$ and $G_{B B A} R 2$ during rat neocortical development," European Journal of Neuroscience, vol. 15, no. 11, pp. 1766-1778, 2002.

[23] T. N. Behar, A. E. Schaffner, C. A. Colton et al., "GABAinduced chemokinesis and NGF-induced chemotaxis of embryonic spinal cord neurons," Journal of Neuroscience, vol. 14, no. 1, pp. 29-38, 1994.

[24] T. N. Behar, Y. Li, H. T. Tran et al., "GABA stimulates chemotaxis and chemokinesis of embryonic cortical neurons via calcium-dependent mechanisms," Journal of Neuroscience, vol. 16, no. 5, pp. 1808-1818, 1996.

[25] G. Lopez-Bendito, R. Lujan, R. Shigemoto, P. Ganter, O. Paulsen, and Z. Molnar, "Blockade of $\mathrm{GABA}_{\mathrm{B}}$ receptors alters the tangential migration of cortical neurons," Cerebral Cortex, vol. 13, no. 9, pp. 932-942, 2003.

[26] H. Fiorentino, N. Kuczewski, D. Diabira et al., " $G A B A_{B}$ receptor activation triggers $\mathrm{BDNF}$ release and promotes the maturation of GABAergic synapses," Journal of Neuroscience, vol. 29, no. 37, pp. 11650-11661, 2009. 
[27] J. R. Cazalets, S. Bertrand, Y. Sqalli-Houssaini, and F. Clarac, "GABAergic control of spinal locomotor networks in the neonatal rat," Annals of the New York Academy of Sciences, vol. 860, pp. 168-180, 1998.

[28] B. Hassfurth, B. Grothe, and U. Koch, "The mammalian interaural time difference detection circuit is differentially controlled by $\mathrm{GABA}_{\mathrm{B}}$ receptors during development," Journal of Neuroscience, vol. 30, no. 29, pp. 9715-9727, 2010.

[29] A. Pfeiffer and W. Zhang, "Postnatal development of GABA ${ }_{B}$ receptor-mediated modulation of potassium currents in brainstem respiratory network of mouse," Respiratory Physiology and Neurobiology, vol. 158, no. 1, pp. 22-29, 2007.

[30] Y. Ben-Ari, J. L. Gaiarsa, R. Tyzio, and R. Khazipov, "GABA: a pioneer transmitter that excites immature neurons and generates primitive oscillations," Physiological Reviews, vol. 87, no. 4, pp. 1215-1284, 2007.

[31] M. J. O'Donovan, “The origin of spontaneous activity in developing networks of the vertebrate nervous system," Current Opinion in Neurobiology, vol. 9, no. 1, pp. 94-104, 1999.

[32] A. G. Blankenship and M. B. Feller, "Mechanisms underlying spontaneous patterned activity in developing neural circuits," Nature Reviews Neuroscience, vol. 11, no. 1, pp. 18-29, 2009.

[33] A. Represa and Y. Ben-Ari, "Trophic actions of GABA on neuronal development," Trends in Neurosciences, vol. 28, no. 6, pp. 278-283, 2005.

[34] C. J. Akerman and H. T. Cline, "Refining the roles of GABAergic signaling during neural circuit formation," Trends in Neurosciences, vol. 30, no. 8, pp. 382-389, 2007.

[35] K. Ganguly, A. F. Schinder, S. T. Wong, and M. M. Poo, "GABA itself promotes the developmental switch of neuronal GABAergic responses from excitation to inhibition," Cell, vol. 105, no. 4, pp. 521-532, 2001.

[36] E. Sernagor, C. Young, and S. J. Eglen, "Developmental modulation of retinal wave dynamics: shedding light on the GABA saga," Journal of Neuroscience, vol. 23, no. 20, pp. 7621-7629, 2003.

[37] W. F. White and A. H. Heller, "Glycine receptor alteration in the mutant mouse spastic," Nature, vol. 298, no. 5875, pp. 655-657, 1982.

[38] T. J. Biscoe and J. P. Fry, "Some pharmacological studies on the spastic mouse," British Journal of Pharmacology, vol. 75, no. 1, pp. 23-35, 1982.

[39] B. A. Graham, P. R. Schofield, P. Sah, and R. J. Callister, "Altered inhibitory synaptic transmission in superficial dorsal horn neurones in spastic and oscillator mice," Journal of Physiology, vol. 551, no. 3, pp. 905-916, 2003.

[40] E. Muller, H. Le Corronc, A. L. Scain, A. Triller, and P. Legendre, "Despite GABAergic neurotransmission, GABAergic innervation does not compensate for the defect in glycine receptor postsynaptic aggregation in spastic mice," European Journal of Neuroscience, vol. 27, no. 10, pp. 2529-2541, 2008.

[41] L. E. Lorenzo, A. Barbe, P. Portalier, J. M. Fritschy, and H. Bras, "Differential expression of $\mathrm{GABA}_{\mathrm{A}}$ and glycine receptors in ALS-resistant vs. ALS-vulnerable motoneurons: possible implications for selective vulnerability of motoneurons," European Journal of Neuroscience, vol. 23, no. 12, pp. 31613170, 2006.

[42] B. Ritter and W. Zhang, "Early postnatal maturation of $\mathrm{GABA}_{\mathrm{A}}$-mediated inhibition in the brainstem respiratory rhythm-generating network of the mouse," European Journal of Neuroscience, vol. 12, no. 8, pp. 2975-2984, 2000.

[43] J. H. Singer, E. M. Talley, D. A. Bayliss, and A. J. Berger, "Development of glycinergic synaptic transmission to rat brain stem motoneurons," Journal of Neurophysiology, vol. 80, no. 5, pp. 2608-2620, 1998.

[44] J. Ren and J. J. Greer, "Modulation of respiratory rhythmogenesis by chloride-mediated conductances during the perinatal period," Journal of Neuroscience, vol. 26, no. 14, pp. 3721-3730, 2006.

[45] J. Brockhaus and K. Ballanyi, "Synaptic inhibition in the isolated respiratory network of neonatal rats," European Journal of Neuroscience, vol. 10, no. 12, pp. 3823-3839, 1998.

[46] R. Tyzio, A. Ivanov, C. Bernard, G. L. Holmes, Y. Ben-Ari, and R. Khazipov, "Membrane potential of CA3 hippocampal pyramidal cells during postnatal development," Journal of Neurophysiology, vol. 90, no. 5, pp. 2964-2972, 2003.

[47] A. Delpy, A. E. Allain, P. Meyrand, and P. Branchereau, "NKCC1 cotransporter inactivation underlies embryonic development of chloride-mediated inhibition in mouse spinal motoneuron," Journal of Physiology, vol. 586, no. 4, pp. 10591075, 2008.

[48] C. Jean-Xavier, G. Z. Mentis, M. J. O’Donovan, D. Cattaert, and L. Vinay, "Dual personality of GABA/glycine-mediated depolarizations in immature spinal cord," Proceedings of the National Academy of Sciences of the United States of America, vol. 104, no. 27, pp. 11477-11482, 2007.

[49] C. A. Hubner, V. Stein, I. Hermans-Borgmeyer, T. Meyer, K. Ballanyi, and T. J. Jentsch, "Disruption of KCC2 reveals an essential role of $\mathrm{K}-\mathrm{Cl}$ cotransport already in early synaptic inhibition," Neuron, vol. 30, no. 2, pp. 515-524, 2001.

[50] A. Stil, S. Liabeuf, C. Jean-Xavier, C. Brocard, J. C. Viemari, and L. Vinay, "Developmental up-regulation of the potassium-chloride cotransporter type 2 in the rat lumbar spinal cord," Neuroscience, vol. 164, no. 2, pp. 809-821, 2009.

[51] W. L. Wu, L. Ziskind-Conhaim, and M. A. Sweet, "Early development of glycine- and GABA-mediated synapses in rat spinal cord," Journal of Neuroscience, vol. 12, no. 10, pp. 3935-3945, 1992.

[52] V. Stein, I. Hermans-Borgmeyer, T. J. Jentsch, and C. A. Hubner, "Expression of the KCl cotransporter KCC2 parallels neuronal maturation and the emergence of low intracellular chloride," Journal of Comparative Neurology, vol. 468, no. 1, pp. 57-64, 2004.

[53] R. Tyzio, R. Cossart, I. Khalilov et al., "Maternal oxytocin triggers a transient inhibitory switch in GABA signaling in the fetal brain during delivery," Science, vol. 314, no. 5806, pp. 1788-1792, 2006.

[54] A. Y. Fong, R. L. Stornetta, C. M. Foley, and J. T. Potts, "Immunohistochemical localization of GAD67-expressing neurons and processes in the rat brainstem: subregional distribution in the nucleus tractus solitarius," Journal of Comparative Neurology, vol. 493, no. 2, pp. 274-290, 2005.

[55] N. Tamamaki, Y. Yanagawa, R. Tomioka, J. I. Miyazaki, K. Obata, and T. Kaneko, "Green fluorescent protein expression and colocalization with calretinin, parvalbumin, and somatostatin in the GAD67-GFP knock-in mouse," Journal of Comparative Neurology, vol. 467, no. 1, pp. 60-79, 2003.

[56] A. E. Allain, A. Bairi, P. Meyrand, and P. Branchereau, "Ontogenic changes of the GABAergic system in the embryonic mouse spinal cord," Brain Research, vol. 1000, no. 1-2, pp. 134-147, 2004.

[57] W. Ma, T. Behar, and J. L. Barker, "Transient expression of GABA immunoreactivity in the developing rat spinal cord," Journal of Comparative Neurology, vol. 325, no. 2, pp. 271290, 1992. 
[58] T. S. Tran, A. Alijani, and P. E. Phelps, "Unique developmental patterns of GABAergic neurons in rat spinal cord," Journal of Comparative Neurology, vol. 456, no. 2, pp. 112-126, 2003.

[59] M. Antal, A. C. Berki, L. Horvath, and M. J. O'Donovan, "Developmental changes in the distribution of gammaaminobutyric acid- immunoreactive neurons in the embryonic chick lumbosacral spinal cord," Journal of Comparative Neurology, vol. 343, no. 2, pp. 228-236, 1994.

[60] L. D. Milner and L. T. Landmesser, "Cholinergic and GABAergic inputs drive patterned spontaneous motoneuron activity before target contact," Journal of Neuroscience, vol. 19, no. 8, pp. 3007-3022, 1999.

[61] P. Branchereau, J. Chapron, and P. Meyrand, "Descending 5-hydroxytryptamine raphe inputs repress the expression of serotonergic neurons and slow the maturation of inhibitory systems in mouse embryonic spinal cord," Journal of Neuroscience, vol. 22, no. 7, pp. 2598-2606, 2002.

[62] M. G. Hanson and L. T. Landmesser, "Characterization of the circuits that generate spontaneous episodes of activity in the early embryonic mouse spinal cord," Journal of Neuroscience, vol. 23, no. 2, pp. 587-600, 2003.

[63] J. Ren and J. J. Greer, "Ontogeny of rhythmic motor patterns generated in the embryonic rat spinal cord," Journal of Neurophysiology, vol. 89, no. 3, pp. 1187-1195, 2003.

[64] H. Nishimaru, M. Iizuka, S. Ozaki, and N. Kudo, "Spontaneous motoneuronal activity mediated by glycine and GABA in the spinal cord of rat fetuses in vitro," Journal of Physiology, vol. 497, no. 1, pp. 131-143, 1996.

[65] M. G. Hanson and L. T. Landmesser, "Normal patterns of spontaneous activity are required for correct motor axon guidance and the expression of specific guidance molecules," Neuron, vol. 43, no. 5, pp. 687-701, 2004.

[66] A. L. Scain, H. Le Corronc, A. E. Allain et al., "Glycine release from radial cells modulates the spontaneous activity and its propagation during early spinal cord development," Journal of Neuroscience, vol. 30, no. 1, pp. 390-403, 2010.

[67] C. P. Myers, J. W. Lewcock, M. G. Hanson et al., "Cholinergic input is required during embryonic development to mediate proper assembly of spinal locomotor circuits," Neuron, vol. 46, no. 1, pp. 37-49, 2005.

[68] M. Rosato-Siri, M. Grandolfo, and L. Ballerini, "Activitydependent modulation of GABAergic synapses in developing rat spinal networks in vitro," European Journal of Neuroscience, vol. 16, no. 11, pp. 2123-2135, 2002.

[69] B. X. Gao, C. Stricker, and L. Ziskind-Conhaim, “Transition from GABAergic to glycinergic synaptic transmission in newly formed spinal networks," Journal of Neurophysiology, vol. 86, no. 1, pp. 492-502, 2001.

[70] K. Nakayama, H. Nishimaru, and N. Kudo, "Basis of changes in left-right coordination of rhythmic motor activity during development in the rat spinal cord," Journal of Neuroscience, vol. 22, no. 23, pp. 10388-10398, 2002.

[71] M. Iizuka, H. Nishimaru, and N. Kudo, "Development of the spatial pattern of 5-HT-induced locomotor rhythm in the lumbar spinal cord of rat fetuses in vitro," Neuroscience Research, vol. 31, no. 2, pp. 107-111, 1998.

[72] T. Fukuroda, S. Ozaki, M. Ihara et al., "Necessity of dual blockade of endothelin ET and ET receptor subtypes for antagonism of endothelin-1-induced contraction in human bronchi," British Journal of Pharmacology, vol. 117, no. 6, pp. 995-999, 1996.

[73] N. Kudo, H. Nishimaru, and K. Nakayama, "Developmental changes in rhythmic spinal neuronal activity in the rat fetus," Progress in Brain Research, vol. 143, pp. 49-55, 2004.
[74] P. Branchereau, D. Morin, A. Bonnot, B. Ballion, J. Chapron, and D. Viala, "Development of lumbar rhythmic networks: from embryonic to neonate locomotor-like patterns in the mouse," Brain Research Bulletin, vol. 53, no. 5, pp. 711-718, 2000.

[75] C. Hinckley, B. Seebach, and L. Ziskind-Conhaim, "Distinct roles of glycinergic and GABAergic inhibition in coordinating locomotor-like rhythms in the neonatal mouse spinal cord," Neuroscience, vol. 131, no. 3, pp. 745-758, 2005.

[76] J. M. Russell, "Sodium-potassium-chloride cotransport," Physiological Reviews, vol. 80, no. 1, pp. 211-276, 2000.

[77] J. Rohrbough and N. C. Spitzer, "Regulation of intracellular $\mathrm{Cl}^{-}$levels by $\mathrm{Na}^{+}$-dependent $\mathrm{Cl}^{-}$cotransport distinguishes depolarizing from hyperpolarizing $\mathrm{GABA}_{\mathrm{A}}$ receptormediated responses in spinal neurons," Journal of Neuroscience, vol. 16, no. 1, pp. 82-91, 1996.

[78] F. J. Alvarez-Leefmans, S. M. Gamino, F. Giraldez, and I. Nogueron, "Intracellular chloride regulation in amphibian dorsal root ganglion neurones studied with ion-selective microelectrodes," Journal of Physiology, vol. 406, pp. 225-246, 1988.

[79] J. A. Payne, T. J. Stevenson, and L. F. Donaldson, "Molecular characterization of a putative $\mathrm{K}-\mathrm{Cl}$ cotransporter in rat brain: a neuronal-specific isoform," Journal of Biological Chemistry, vol. 271, no. 27, pp. 16245-16252, 1996.

[80] C. Rivera, J. Voipio, J. A. Payne et al., "The $\mathrm{K}^{+} / \mathrm{Cl}^{-}$co-transporter KCC2 renders GABA hyperpolarizing during neuronal maturation," Nature, vol. 397, no. 6716, pp. 251-255, 1999.

[81] M. Farrant and K. Kaila, "The cellular, molecular and ionic basis of $\mathrm{GABA}_{\mathrm{A}}$ receptor signalling," Progress in Brain Research, vol. 160, pp. 59-87, 2007.

[82] C. Z. Wang, H. Yano, K. Nagashima, and S. Seino, “The Nadriven $\mathrm{Cl} / \mathrm{HCO}$ / exchanger: cloning, tissue distribution, and functional characterization," Journal of Biological Chemistry, vol. 275, no. 45, pp. 35486-35490, 2000.

[83] M. Chesler, "Regulation and modulation of $\mathrm{pH}$ in the brain," Physiological Reviews, vol. 83, no. 4, pp. 1183-1221, 2003.

[84] M. F. Romero, C. M. Fulton, and W. F. Boron, "The SLC4 family of HCO transporters," Pflugers Archiv European Journal of Physiology, vol. 447, no. 5, pp. 495-509, 2004.

[85] R. G. Giffard, Y. S. Lee, Y. B. Ouyang, S. L. Murphy, and H. Monyer, "Two variants of the rat brain sodium-driven chloride bicarbonate exchanger (NCBE): developmental expression and addition of a PDZ motif," European Journal of Neuroscience, vol. 18, no. 11, pp. 2935-2945, 2003.

[86] Y. Ben-Ari, "Excitatory actions of gaba during development: the nature of the nurture," Nature Reviews Neuroscience, vol. 3, no. 9, pp. 728-739, 2002.

[87] Y. Ben-Ari, "Developing networks play a similar melody," Trends in Neurosciences, vol. 24, no. 6, pp. 353-360, 2001.

[88] D. F. Owens and A. R. Kriegstein, "Is there more to GABA than synaptic inhibition?" Nature Reviews Neuroscience, vol. 3, no. 9, pp. 715-727, 2002.

[89] C. Gonzalez-Islas, N. Chub, and P. Wenner, "NKCC1 and AE3 appear to accumulate chloride in embryonic motoneurons," Journal of Neurophysiology, vol. 101, no. 2, pp. 507518, 2009.

[90] C. A. Hübner, M. Hentschke, S. Jacobs, and I. HermansBorgmeyer, "Expression of the sodium-driven chloride bicarbonate exchanger NCBE during prenatal mouse development," Gene Expression Patterns, vol. 5, no. 2, pp. 219-223, 2004. 
[91] J. W. Lynch, "Molecular structure and function of the glycine receptor chloride channel," Physiological Reviews, vol. 84, no. 4, pp. 1051-1095, 2004.

[92] R. L. Macdonald and R. W. Olsen, "GABA receptor channels," Annual Review of Neuroscience, vol. 17, pp. 569-602, 1994.

[93] M. Farrant and Z. Nusser, "Variations on an inhibitory theme: phasic and tonic activation of $\mathrm{GABA}_{\mathrm{A}}$ receptors," Nature Reviews Neuroscience, vol. 6, no. 3, pp. 215-229, 2005.

[94] I. Brünig, E. Scotti, C. Sidler, and J. M. Fritschy, "Intact sorting, targeting, and clustering of $\gamma$-aminobutyric acid A receptor subtypes in hippocampal neurons in vitro," Journal of Comparative Neurology, vol. 443, no. 1, pp. 43-55, 2002.

[95] F. Crestani, R. Keist, J. M. Fritschy et al., "Trace fear conditioning involves hippocampal $\alpha_{5} \mathrm{GABA}_{\mathrm{A}}$ receptors," Proceedings of the National Academy of Sciences of the United States of America, vol. 99, no. 13, pp. 8980-8985, 2002.

[96] S. I. Storustovu and B. Ebert, "Pharmacological characterization of agonists at delta-containing $\mathrm{GABA}_{\mathrm{A}}$ receptors: functional selectivity for extrasynaptic receptors is dependent on the absence of gamma2," Journal of Pharmacology and Experimental Therapeutics, vol. 316, no. 3, pp. 1351-1359, 2006.

[97] K. J. Gingrich, W. A. Roberts, and R. S. Kass, "Dependence of the $\mathrm{GABA}_{\mathrm{A}}$ receptor gating kinetics on the $\alpha$-subunit isoform: implications for structure-function relations and synaptic transmission," Journal of Physiology, vol. 489, no. 2, pp. 529-543, 1995.

[98] W. Wisden, A. L. Gundlach, E. A. Barnard, P. H. Seeburg, and S. P. Hunt, "Distribution of $\mathrm{GABA}_{\mathrm{A}}$ receptor subunit mRNAs in rat lumbar spinal cord," Molecular Brain Research, vol. 10, no. 2, pp. 179-183, 1991.

[99] J. M. Fritschy and H. Mohler, "GABA$A_{A}$-receptor heterogeneity in the adult rat brain: differential regional and cellular distribution of seven major subunits," Journal of Comparative Neurology, vol. 359, no. 1, pp. 154-194, 1995.

[100] H. J. Waldvogel, K. Baer, E. Eady et al., "Differential localization of gamma-aminobutyric acid type A and glycine receptor subunits and gephyrin in the human pons, medulla oblongata and uppermost cervical segment of the spinal cord: an immunohistochemical study," The Journal of Comparative Neurology, vol. 518, no. 3, pp. 305-328, 2010.

[101] C. B. Saper, "A guide to the perplexed on the specificity of antibodies," Journal of Histochemistry and Cytochemistry, vol. 57, no. 1, pp. 1-5, 2009.

[102] E. M. Schneider Gasser, C. J. Straub, P. Panzanelli, O. Weinmann, M. Sassoè-Pognetto, and J. M. Fritschy, "Immunofluorescence in brain sections: simultaneous detection of presynaptic and postsynaptic proteins in identified neurons," Nature Protocols, vol. 1, no. 4, pp. 1887-1897, 2006.

[103] W. Ma, P. A. Saunders, R. Somogyi, M. O. Poulter, and J. L. Barker, "Ontogeny of $\mathrm{GABA}_{\mathrm{A}}$ receptor subunit mRNAs in rat spinal cord and dorsal root ganglia," Journal of Comparative Neurology, vol. 338, no. 3, pp. 337-359, 1993.

[104] P. Legendre, "The glycinergic inhibitory synapse," Cellular and Molecular Life Sciences, vol. 58, no. 5-6, pp. 760-793, 2001.

[105] E. Muller, A. Triller, and P. Legendre, "Glycine receptors and GABA receptor alpha 1 and gamma 2 subunits during the development of mouse hypoglossal nucleus," European Journal of Neuroscience, vol. 20, no. 12, pp. 3286-3300, 2004.

[106] J. M. Fritschy, J. Paysan, A. Enna, and H. Mohler, "Switch in the expression of rat $\mathrm{GABA}_{\mathrm{A}}$-receptor subtypes during postnatal development: an immunohistochemical study," Journal of Neuroscience, vol. 14, no. 9, pp. 5302-5324, 1994.

[107] L. E. Lorenzo, M. Russier, A. Barbe, J. M. Fritschy, and H. Bras, "Differential organization of gamma-aminobutyric acid type A and glycine receptors in the somatic and dendritic compartments of rat abducens motoneurons," The Journal of Comparative Neurology, vol. 504, no. 2, pp. 112-126, 2007.

[108] V. C. Kotak, S. Korada, I. R. Schwartz, and D. H. Sanes, "A developmental shift from GABAergic to glycinergic transmission in the central auditory system," Journal of Neuroscience, vol. 18, no. 12, pp. 4646-4655, 1998.

[109] J. Nabekura, S. Katsurabayashi, Y. Kakazu et al., "Developmental switch from GABA to glycine release in single central synaptic terminals," Nature Neuroscience, vol. 7, no. 1, pp. 1723, 2004.

[110] J. Meier, R. Juttner, S. Kirischuk, and R. Grantyn, "Synaptic anchoring of glycine receptors in developing collicular neurons under control of metabotropic glutamate receptor activity," Molecular and Cellular Neuroscience, vol. 21, no. 2, pp. 324-340, 2002.

[111] P. Jonas, J. Bischofberger, and J. Sandkühler, "Corelease of two fast neurotransmitters at a central synapse," Science, vol. 281, no. 5375, pp. 419-424, 1998.

[112] J. A. O’Brien and A. J. Berger, "Cotransmission of GABA and glycine to brain stem motoneurons," Journal of Neurophysiology, vol. 82, no. 3, pp. 1638-1641, 1999.

[113] J. A. O'Brien and A. J. Berger, "The nonuniform distribution of the $\mathrm{GABA}_{\mathrm{A}}$ receptor $\alpha 1$ subunit influences inhibitory synaptic transmission to motoneurons within a motor nucleus," Journal of Neuroscience, vol. 21, no. 21, pp. 84828494, 2001.

[114] E. J. Geiman, W. Zheng, J. M. Fritschy, and F. J. Alvarez, "Glycine and $\mathrm{GABA}_{\mathrm{A}}$ receptor subunits on renshaw cells: relationship with presynaptic neurotransmitters and postsynaptic gephyrin clusters," Journal of Comparative Neurology, vol. 444, no. 3, pp. 275-289, 2002.

[115] A. F. Keller, J. A. M. Coull, N. Chéry, P. Poisbeau, and Y. De Koninck, "Region-specific developmental specialization of GABA-glycine cosynapses in laminas I-II of the rat spinal dorsal horn," Journal of Neuroscience, vol. 21, no. 20, pp. 7871-7880, 2001.

[116] D. Gonzalez-Forero and F. J. Alvarez, "Differential postnatal maturation of $\mathrm{GABA}_{\mathrm{A}}$, glycine receptor, and mixed synaptic currents in Renshaw cells and ventral spinal interneurons," Journal of Neuroscience, vol. 25, no. 8, pp. 2010-2023, 2005.

[117] A. Dufour, F. Tell, and A. Baude, "Perinatal development of inhibitory synapses in the nucleus tractus solitarii of the rat," European Journal of Neuroscience, vol. 32, no. 4, pp. 538-549, 2010.

[118] E. Muller, H. Le Corronc, A. Triller, and P. Legendre, "Developmental dissociation of presynaptic inhibitory neurotransmitter and postsynaptic receptor clustering in the hypoglossal nucleus," Molecular and Cellular Neuroscience, vol. 32, no. 3, pp. 254-273, 2006.

[119] A. Dumoulin, A. Triller, and S. Dieudonné, "IPSC kinetics at identified GABAergic and mixed GABAergic and glycinergic synapses onto cerebellar Golgi cells," Journal of Neuroscience, vol. 21, no. 16, pp. 6045-6057, 2001.

[120] C. Takayama and Y. Inoue, "Morphological development and maturation of the GABAergic synapses in the mouse cerebellar granular layer," Developmental Brain Research, vol. 150, no. 2, pp. 177-190, 2004.

[121] Z. Nusser, W. Sieghart, D. Benke, J. M. Fritschy, and P. Somogyi, "Differential synaptic localization of two major 
gamma-aminobutyric acid type A receptor alpha subunits on hippocampal pyramidal cells," Proceedings of the National Academy of Sciences of the United States of America, vol. 93, no. 21, pp. 11939-11944, 1996.

[122] Z. Nusser, W. Sieghart, and P. Somogyi, "Segregation of different $\mathrm{GABA}_{\mathrm{A}}$ receptors to synaptic and extrasynaptic membranes of cerebellar granule cells," Journal of Neuroscience, vol. 18, no. 5, pp. 1693-1703, 1998.

[123] A. J. Todd, C. Watt, R. C. Spike, and W. Sieghart, "Colocalization of GABA, glycine, and their receptors at synapses in the rat spinal cord," Journal of Neuroscience, vol. 16, no. 3, pp. 974-982, 1996.

[124] K. Kannenberg, W. Sieghart, and H. Reuter, "Clusters of $\mathrm{GABA}_{\mathrm{A}}$ receptors on cultured hippocampal cells correlate only partially with functional synapses," European Journal of Neuroscience, vol. 11, no. 4, pp. 1256-1264, 1999.

[125] A. Rao, E. M. Cha, and A. M. Craig, "Mismatched appositions of presynaptic and postsynaptic components in isolated hippocampal neurons," Journal of Neuroscience, vol. 20, no. 22 , pp. 8344-8353, 2000.

[126] E. Muller, H. Le-Corronc, and P. Legendre, "Extrasynaptic and postsynaptic receptors in glycinergic and GABAergic neurotransmission: a division of labor?" Frontiers in Molecular Neuroscience, vol. 1, no. 3, 2008.

[127] S. F. Kingsmore, B. Giros, D. Suh, M. Bieniarz, M. G. Caron, and M. F. Seldin, "Glycine receptor $\beta$-subunit gene mutation in spastic mouse associated with LINE-1 element insertion," Nature Genetics, vol. 7, no. 2, pp. 136-142, 1994.

[128] C. Mulhardt, M. Fischer, P. Gass et al., "The spastic mouse: aberrant splicing of glycine receptor $\beta$ subunit mRNA caused by intronic insertion of L1 element," Neuron, vol. 13, no. 4, pp. 1003-1015, 1994.

[129] C. M. Becker, I. Hermans-Borgmeyer, B. Schmitt, and H. Betz, "The glycine receptor deficiency of the mutant mouse spastic: evidence for normal glycine receptor structure and localization," Journal of Neuroscience, vol. 6, no. 5, pp. 13581364, 1986.

[130] S. Petri, K. Krampfl, F. Hashemi et al., "Distribution of $\mathrm{GABA}_{\mathrm{A}}$ receptor mRNA in the motor cortex of ALS patients," Journal of Neuropathology and Experimental Neurology, vol. 62, no. 10, pp. 1041-1051, 2003.

[131] A. Reiner, L. Medina, G. Figueredo-Cardenas, and S. Anfinson, "Brainstem motoneuron pools that are selectively resistant in amyotrophic lateral sclerosis are preferentially enriched in parvalbumin: evidence from monkey brainstem for a calcium-mediated mechanism in sporadic ALS," Experimental Neurology, vol. 131, no. 2, pp. 239-250, 1995.

[132] M. Scanziani, "GABA spillover activates postsynaptic $G_{A B A}$ receptors to control rhythmic hippocampal activity," Neuron, vol. 25, no. 3, pp. 673-681, 2000.

[133] I. Mody and R. A. Pearce, "Diversity of inhibitory neurotransmission through $\mathrm{GABA}_{\mathrm{A}}$ receptors," Trends in Neurosciences, vol. 27, no. 9, pp. 569-575, 2004.

[134] E. Syková, "Extrasynaptic volume transmission and diffusion parameters of the extracellular space," Neuroscience, vol. 129, no. 4, pp. 861-876, 2004.

[135] E. M. Petrini, I. Marchionni, P. Zacchi, W. Sieghart, and E. Cherubini, "Clustering of extrasynaptic $\mathrm{GABA}_{\mathrm{A}}$ receptors modulates tonic inhibition in cultured hippocampal neurons," Journal of Biological Chemistry, vol. 279, no. 44, pp. 45833-45843, 2004.

[136] Q. Chang and L. J. Martin, "Glycinergic innervation of motoneurons is deficient in amyotrophic lateral sclerosis mice: a quantitative confocal analysis," American Journal of Pathology, vol. 174, no. 2, pp. 574-585, 2009.

[137] Q. Chang and L. J. Martin, "Glycine receptor channels in spinal motoneurons are abnormal in a transgenic mouse model of amyotrophic lateral sclerosis," Journal of Neuroscience, vol. 31, no. 8, pp. 2815-2827, 2011.

[138] G. B. Banks, R. Kanjhan, S. Wiese et al., "Glycinergic and GABAergic synaptic activity differentially regulate motoneuron survival and skeletal muscle innervation," Journal of Neuroscience, vol. 25, no. 5, pp. 1249-1259, 2005.

[139] P. Somogyi, G. Tamás, R. Lujan, and E. H. Buhl, "Salient features of synaptic organisation in the cerebral cortex," Brain Research Reviews, vol. 26, no. 2-3, pp. 113-135, 1998. 

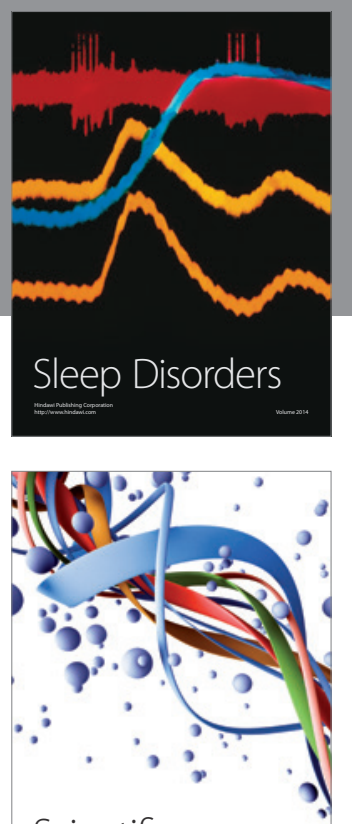

Scientifica
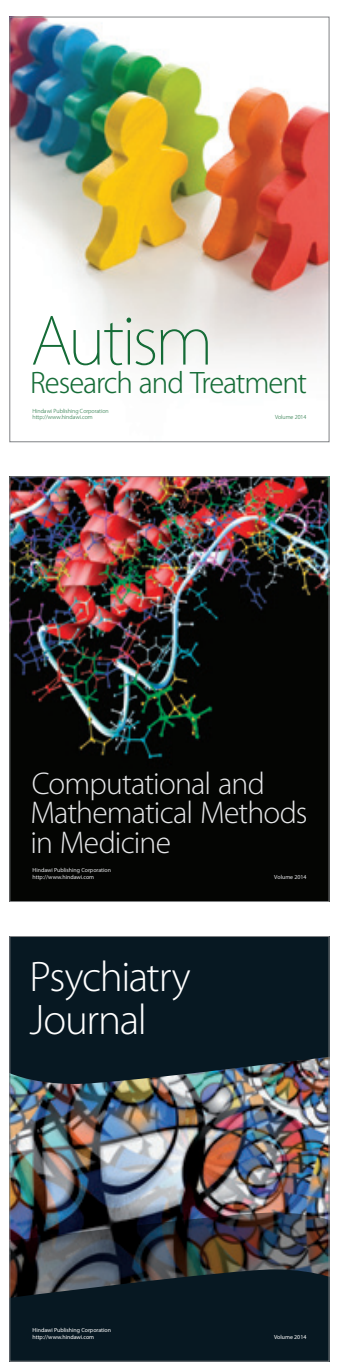
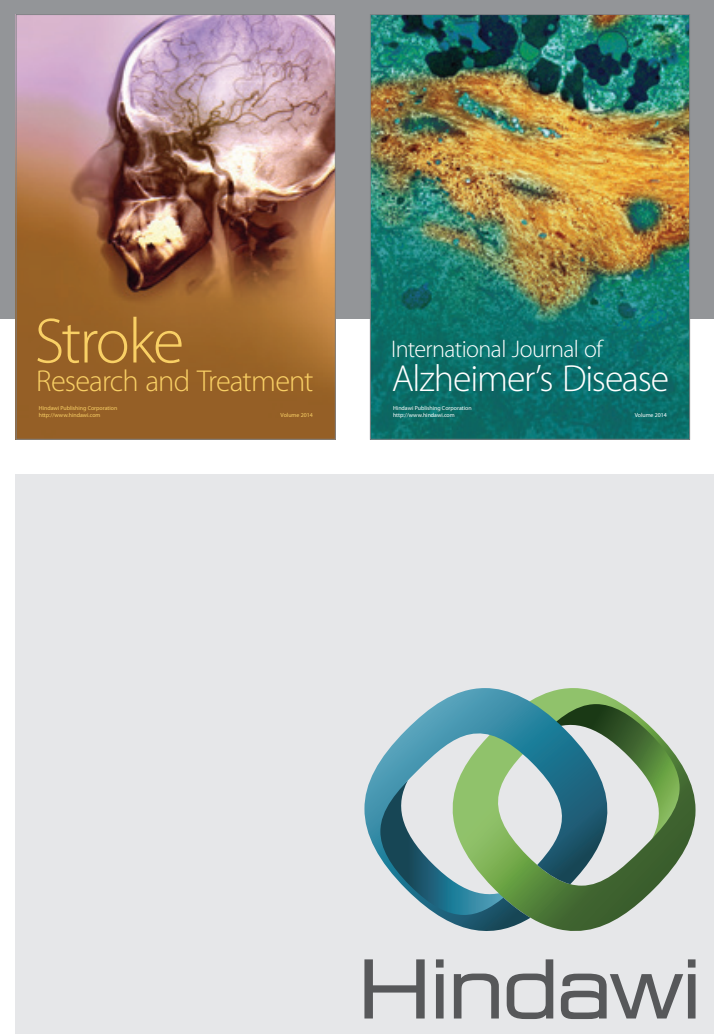

Submit your manuscripts at

http://www.hindawi.com
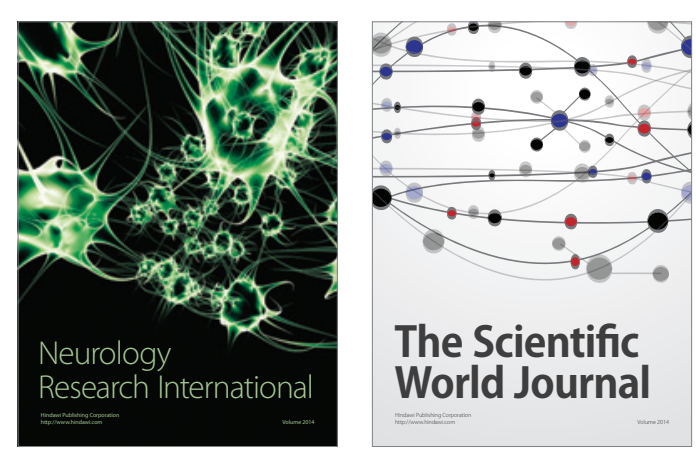

The Scientific World Journal

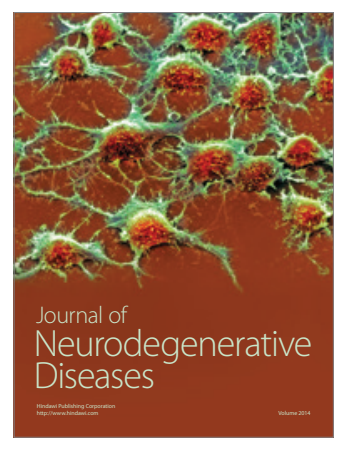

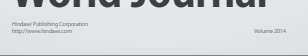

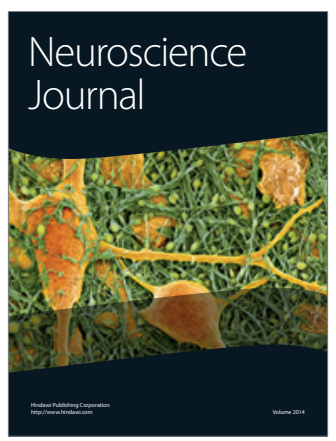

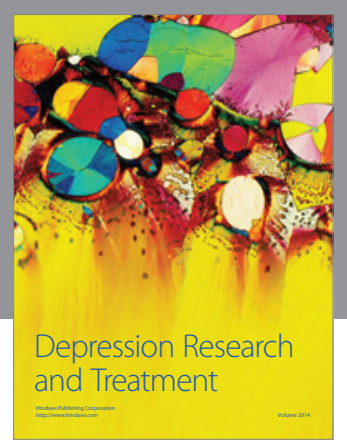
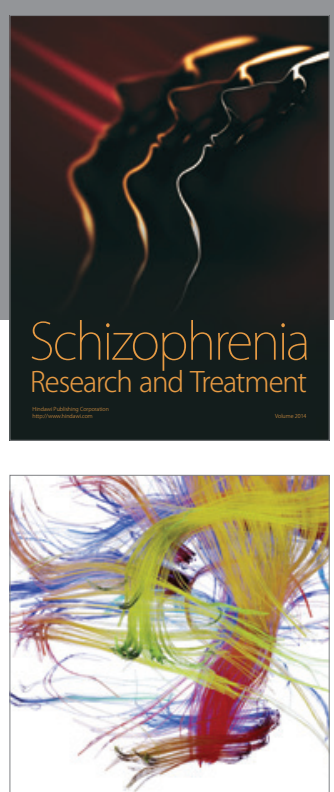

Brain Science

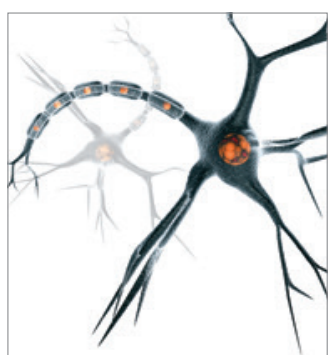

Neural Plasticity
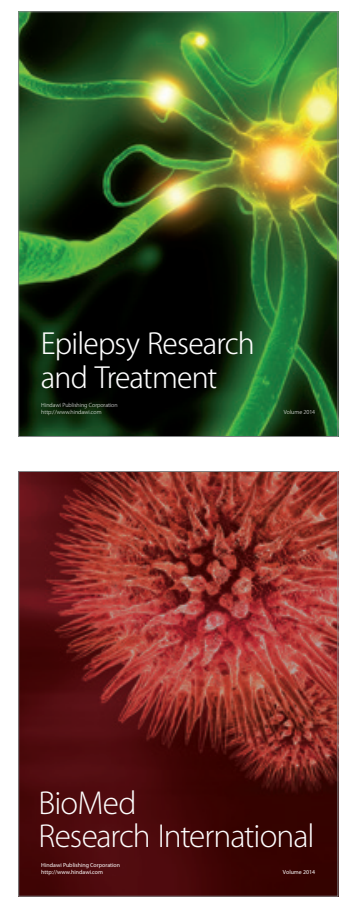

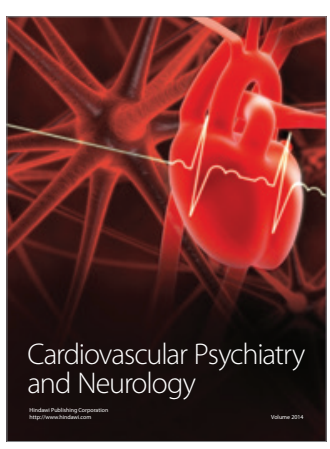

Parkinson's

Disease
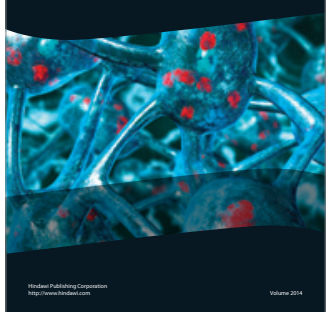